Marquette University

e-Publications@Marquette

$1-1-1981$

\title{
What Do Labor Productivity Data Show about Economies of Scale: Comment
}

Brian Brush

Marquette University, brian.brush@marquette.edu

Published version. Southern Economic Journal,Vol. 47, No. 3 (January 1981): 839-846. Stable URL (C) 1981 Southern Economic Association. Used with permission. 


\section{What Do Labor Productivity Data Show about Economies of Scale: Comment*}

\section{Introduction}

In a recent article, Edward Miller attempted to draw inferences about the extent of economies of scale from comparisons of the labor productivity of firms of different sizes in the same industry [5]. More specifically, he used various measures of labor productivity, including value of shipments per employee, valued added per employee, "profits" per employee, and value of raw materials processed per employee, and, for a sample of 448 four-digit U.S. manufacturing industries, he compared the average labor productivity of the largest four firms to the average labor productivity of the rest of the firms in the same industry, using 1972 Census data [14]. He reported that, regardless of the measure of labor productivity employed, the largest four firms had the higher labor productivity in the vast majority of cases, and that, "on average", the largest four firms enjoyed a labor productivity advantage over the "rest of the industry" that ranged from 37 percent (value added) to 57 percent ("profits").

Miller's was not the first study to interpret such labor productivity data as evidence on economies of scale. ${ }^{1}$ However, his was the first to draw the momentous conclusion that "compelling evidence of large economies of scale at the firm level for a major portion of American industry" had now been uncovered [5, 486]. The purpose of this paper is to demonstrate that this claim is overblown and unwarranted, and that the evidence, in fact, is far from compelling.

This paper is organized into two main sections. In the immediately following section it is shown that, even if the observed labor productivity differences do reflect economies of scale (hardly the only plausible interpretation), Miller's tests greatly exaggerate their importance. Then, in the next section, alternative explanations for the observed labor productivity differences are briefly noted, and some indirect evidence is presented which is based on a modified survivor technique. This evidence, while consistent with a number of plausible alternative hypotheses, is inconsistent with the scale economies interpretation. In the final section, some less-than-momentous conclusions are offered.

\section{The Exaggerated Extent of Economies of Scale}

Even if the labor productivity differences reported by Miller reflect economies of scale, there are good reasons for believing that the importance of economies of scale has been exagger-

* This research was supported by a Summer Faculty Fellowship awarded by the College of Business Administration at Marquette University.

1. See, for example, Caves, Khalilzadeh-Shirazi, and Porter [4], who apply a similar technique to plant size distributions. For a critique of their methods, see Brush [3]. 
ated in the Miller study. For example, he reports that in 374 of 448 industries ( 83 percent), the largest four firms had greater value added per employee than did the "rest of the industry". (The "rest of the industry" had the greater value added per employee in 48 , or 11 percent, of the cases.) No serious student of economies of scale would find this result surprising, implying as it does merely that there are some economies of scale in most industries and that the largest four firms in most industries are, on the average, not so large as to encounter serious diseconomies of scale. ${ }^{2}$ But Miller's approach leaves the impression (he does not state it explicitly) that the largest four firms nearly always have higher labor productivity than all of the other firms in the industry, and that firms have to be at least as large as the "Big Four" in order to be optimally efficient. Of course, the fact that the "Big Four" have higher labor productivity than the average for the "rest of the industry" does not necessarily imply that they have higher labor productivity than the firms ranked 5th through 8th in size, or for that matter, firms even smaller. The really important empirical problems with respect to economies of scale, laden with policy implications, are to estimate minimum optimal firm size, its relationship to the size of the market, and the resultant minimum level of market concentration consistent with efficiency. Despite the title of his article, Miller provides little evidence on these questions and on the "extent of economies of scale" within individual industries.

The foregoing suggests that it might be worthwhile to compare the labor productivity of the largest four firms with that of the "next four largest firms", rather than with the "rest of the industry". Since it seems not to matter greatly which measure of labor productivity is employed, the ratio of value added per employee (four largest firms) to value added per employee (next four largest firms) has been calculated for each of 444 Census manufacturing industries for which the requisite data were available for 1972. The size distribution of these ratios appears in Table $I^{3}$

Those who choose to interpret labor productivity data as evidence of economies of scale will still find support in Table I for the proposition that economies of scale frequently extend out to the size of the largest four firms. The largest four firms have the higher labor productivity in 282 out of 444 cases (64 percent). Still, the superiority of the largest four firms appears to be much less pervasive than Miller's comparison suggested. And if these 282 cases imply economies of scale, then presumably there are 150 industries (34 percent of the total) in which diseconomies of scale exist. In 57 of these industries (13 percent of the total sample) the "next four largest firms" have a labor productivity advantage of more than 25 percent over the largest four firms.

While the incidence of cases in which the largest four firms have the advantage is greatly reduced by this approach as compared to Miller's, so too is the average magnitude of the advantage. The median ratio for the entire 444 industry sample is only 1.10 , and the geometric mean is 1.12. These figures imply an "average" advantage for the largest four firms far less than the 37 percent reported by Miller, ${ }^{4}$ and are of an order of magnitude which oth-

2. As for the "average" 37 percent large-firm advantage, this may be highly misleading, as noted below.

3. The seemingly odd size class limits serve the interest of symmetry. While a ratio of 1.50 implies a 50 percent greater labor productivity by the four largest firms, a ratio of 0.67 implies approximately a 50 percent greater labor productivity by the next four largest firms compared to the four largest.

4. While it is not entirely clear, it appears that the average 37 percent advantage in value added per employee (and other similar figures reported by Miller) was obtained by calculating a simple average of the ratios of value added per employee (largest four firms) to value added per employee (rest of industry). If so, a faulty procedure has been used. Suppose, for example, that in half of the industries in the sample the largest four firms have twice the labor productivity of the rest of the industry (ratio of 2.0), while in the other half, the rest of the industry has twice the labor productivity of the largest four firms (ratio of 0.50 ). The simple arithmetic mean of the ratios would be 
Table I. Distribution of the Ratio of Value Added per Employee (four largest firms) to Value Added per Employee (next four largest firms), 1972

\begin{tabular}{|c|c|}
\hline Range of Ratio & No. of Industries \\
\hline $0.00-0.49$ & 4 \\
\hline $0.50-0.66$ & 16 \\
\hline $0.67-0.79$ & 37 \\
\hline $0.80-0.99$ & 93 \\
\hline $1.00-1.00$ & 12 \\
\hline $1.01-1.25$ & 136 \\
\hline $1.26-1.50$ & 84 \\
\hline $1.51-2.00$ & 47 \\
\hline Over 2.00 & 15 \\
\hline & Total \\
\hline
\end{tabular}

Source: Calculated from data in U.S. Bureau of the Census [14].

ers have suggested might easily be explained away by factors other than economies of scale. ${ }^{5}$ While there may in fact be many individual industries in which important economies of scale extend out to the size of the largest firms (in Table I, there are 146 industries for which the calculated "relative labor productivity ratio" exceeds 1.25 ), by the same reasoning there appear also to be many industries (albeit fewer) in which important diseconomies exist, and the overall picture is not nearly as one-sided as that painted by Miller.

One further point is worthy of mention before closing out this section. Even if labor productivity differences reflect economies of scale, and even if the largest four firms have substantially higher labor productivity than the next four largest firms, it still does not follow that a firm needs to be anywhere near as large as the largest four firms in order to be optimally efficient. This is because there often is a considerable disparity in size between the "Big Four" and the "Next Four" firms. For example, in the breakfast cereal industry (SIC 2043), the largest four firms had a 47 percent higher value added per worker than the "Next Four" in 1972. But in terms of value of shipments, the average member of the "Big Four"

1.25 , but surely it would be inappròpriate to conclude that, "on average", the largest four firms had 25 percent more value added per employee. With this kind of data, the geometric mean is more appropriate. For the example given, its value would be 1.00 .

5. See Caves, Khalilizadeh-Shirazi, and Porter [4]. It should be noted that this study, while employing the same kind of measure as did Miller's, was concerned with estimating the importance of scale economies at the plant level, and did not use precisely the same measure as discussed in this paper. 
was eleven times as large as the average member of the "Next Four". Conceivably, being merely five times as large might have sufficed to take advantage of all economies of scale. ${ }^{6}$

\section{The Soundness of the Scale Economies Interpretation}

Given the various alternative explanations for differences in labor productivity, it is a mystery why anyone would seize upon scale economies as the explanation. Firms of different sizes in the same Census industry may differ with respect to labor productivity (as measured by value added per employee) for many reasons. They may differ in capital intensity, the quality of their labor inputs, the extent of monopsony power, the extent to which they utilize purchased services, such as advertising and telephone, the geographical market they serve, the extent to which they enjoy product differentiation advantages, and the product or product mixes which they are engaged in producing. Miller attempted to deal with several of these factors, although not in an entirely convincing manner, but other possible explanations were all but ignored.

One factor which would seem to merit more consideration that it has received are differences in product or product mix. While Miller writes of the "fine level of detail" characterizing the four-digit Census industries [5, 470], there appears to be a consensus that, more often than not, the four digit Census industry definitions are excessively broad and encompass non-competing and essentially different products $[2,132 ; 8,57 ; 11,199]$. To take just one among numerous ready examples, one must wonder how meaningful it is to assert that the four largest producers in SIC 3711 (Motor Vehicles and Passenger Car Bodies) had 57 percent greater value added per employee than did the next four largest firms in 1972. Presumably the four largest firms produced a lot of passenger automobiles, but the next four largest firms must have been principally engaged in producing large highway trucks, or buses, or armored cars, or fire engines, or universal military carriers, or one of the several other products classified in SIC 3711.

Unfortunately, the kinds of consistent and comparable data necessary to sort out all the various possible causes of labor productivity differentials among different firm sizes for a large sample of individual industries are not available. In this section, a variant of the survivor technique is used to provide some indirect evidence on the validity of Miller's scaleeconomies hypothesis. ${ }^{8}$ If the largest firms have a truly substantial efficiency advantage over other firms, it is reasonable to expect that they will increase their market shares over time. This is true regardless of whether the efficiency advantage reflects real and socially beneficial, or merely pecuniary and private, advantages of size. Applying the technique in reverse, if top-level concentration does not increase in industries in which the largest four firms have substantially higher labor productivity than the next four firms, this would certainly cast doubt on the validity of the scale-economies hypothesis.

One problem with applying this test is that the data on value added per employee are quite volatile from one Census year to another. The four largest firms may appear to have a

6. It must be recognized, on the other hand, that in some cases there may be only one or even no firms of minimum optimal scale in the industry. Unfortunately, the data exist only for groups of four or more firms.

7. Imported automobiles are, of course, not counted in the Census figures, and there were only four significant domestic producers of automobiles in 1972.

8. Examples of the use of the survivor technique to estimate economies of scale include the studies of Stigler [12], Saving [7], Weiss [15], and Shepherd [10]. 
Table II. Examples of Shifts in the Ratio of Value Added per Employee (four largest firms) to Value Added per Employee (next four largest firms), 1967 to 1972

\begin{tabular}{ccc}
\hline SIC No. & $\frac{196 i \text { Ratio }}{1972 \text { Ratio }}$ \\
2282 & 0.65 & 1.44 \\
2323 & 2.06 & 0.65 \\
2541 & 2.33 & 0.45 \\
3281 & 0.67 & 1.62 \\
3442 & 2.14 & 0.73 \\
3672 & 2.74 & 1.02 \\
3715 & 0.77 & 1.55 \\
\hline
\end{tabular}

substantial labor productivity advantage in one Census year, and a substantial disadvantage in the immediately preceding (or following) Census year. For the 343 Census industries for which comparable data are available for 1967 and 1972, the labor productivity advantage switched between the "Big Four" and the "Next Four" in 111 industries $(32$ percent of the cases) between the two Census years.' Table II shows a few of the more prominent examples. For the entire sample, the correlation between the 1967 and 1972 ratios of value added per employee (four largest firms) to value added per employee (next four largest firms) is only +0.33 .

To get around the problem of data volatility, all industries were identified for which the "relative labor productivity ratio" exceeded 1.25 in both 1967 and 1972, and the changes in the value of shipments four-firm concentration ratios between 1967 and 1972 were computed for these industries. Since very small changes in concentration ratios typically mean little because of the effects of random elements and/or rounding errors, it is appropriate to focus on non-trivial changes, and this philosophy is reflected in Table III, which shows the frequency distribution of concentration changes for the 67 industries for which the relative labor productivity ratio exceeded 1.25 in both 1967 and 1972 .

In Table III it can be observed that only 24 of the 67 industries ( 36 percent) exhibited positive concentration changes as large as three percentage points, with 12 (18 percent) showing increases of six percentage points or more. For the entire sample of 343 industries, 107 (31 percent) had increases of three percentage points or more, with 49 (14 percent) showing increases of six percentage points or more. In spite of what some would interpret as a substantial efficiency advantage for the largest four firms, ${ }^{10}$ the 67 industry sub-sample did

9. The raw data for 1967 can be found in U.S. Bureau of the Census [13].

10. For the 67 industry sub-sample, the relative labor productivity ratios ranged from 1.25 to 4.03 , with a median of 1.58 , in 1972. 
Table III. Frequency Distribution of Four-Firm Concentration Ratio Changes, All Industries for Which the Ratio of Value Added per Employee (four largest firms) to Value Added per Employee (next four largest firms) Exceeded 1.25 in Both 1967 and 1972

\begin{tabular}{cc}
$\begin{array}{c}\text { Concentration Change } \\
\text { (Percentage Points) }\end{array}$ & No. of Industries \\
\cline { 2 - 3 }-12 and Down & 1 \\
-9 to -11 & 3 \\
-6 to -8 & 2 \\
-3 to -5 & 5 \\
-2 to +2 & 32 \\
+3 to +5 & 12 \\
+6 to +8 & 6 \\
+9 to +11 & 3 \\
+12 and Up & Total \\
\end{tabular}

Source: Computed from U.S. Bureau of the Census [13; 14].

not behave much differently with respect to concentration changes than the sample as a whole. While other factors may also be at work here, it should be noted that, although the mean 1967 four-firm concentration ratio for the 67-industry sub-sample is higher than the mean ratio for the sample as a whole ( 46.8 to 38.4 ), it does not appear high enough to inhibit further increases in concentration, and an examination of individual cases suggests that this factor has little effect on the validity of the comparison made.

Perhaps a 25 percent labor productivity advantage is not large enough to imply significant economies of scale, given the other possible explanations for the difference, although it should be noted that the number of cases of "significant" economies of scale tends to drop rapidly as one raises the criterion ratio. In Table IV is displayed the frequency distribution of the 1967-72 concentration changes for the 27 industries for which the relative labor productivity ratio exceeded 1.50 in both 1967 and 1972. By Miller's interpretation, the largest four firms in each of these industries should have a truly thumping efficiency advantage over the next four largest firms. " Concentration increases of three percentage points or more occurred in only seven ( 26 percent) of these industries, and increases of six percentage points or more occurred in only four (15 percent). The results are virtually indistinguishable from

11. For these 27 industries, the relative labor productivity ratio ranged from 1.50 to 3.23 , with a median of 1.88 , in 1972. 
Table IV. Frequency Distribution of Four-Firm Concentration Ratio Changes, All Industries for Which the Ratio of Value Added per Employee (four largest firms) to Value Added per Employee (next four largest firms) Exceeded 1.50 in Both 1967 and 1972

\section{Concentration Change \\ (Percentage Points)}

-12 and Down

-9 to -11

-6 to -8

-3 to -5

-2 to +2

+3 to +5

+6 to +8

+9 to +11

+12 and Up
No. of Industries

2

0

1

2

15

3

2

0

Total $\frac{2}{27}$

Source: Computed from U.S. Bureau of the Census [13; 14].

those for the sample as a whole, and are inconsistent with the scale economies hypothesis, although they are perfectly consistent with some of the other possible explanations, including the possibility that firms of different sizes are producing different products or product mixes.

\section{Concluding Remarks}

The extent of economies of scale is an empirical question with tremendous implications for the making of public policy. Unfortunately, no method of estimation has yet been developed that is both reasonably reliable and easy in its application over a wide range of industry. As the arguments and results of this paper make clear, Miller's "scale-economies" interpretation of labor productivity data is open to serious question. When it comes to estimating economies of scale at the firm level, there at present appears to be no acceptable substitute for the laborious procedures of Bain [1], Pratten [6], and Scherer et al. [9], who have produced such estimates for a relatively small number of manufacturing industries in the U.S., Great Britain, and elsewhere. Given the complexity of the scale economies estimation problem, no po- 
tential source of information should be ignored, but at the same time, simplistic interpretations must be avoided.

Brian C. Brush

Marquette University

Milwaukee, Wisconsin

\section{References}

1. Bain, Joe S. Barriers to New Competition. Cambridge, Mass.: Harvard University Press, 1956.

2. Bain, Joe S. Industrial Organization, 2nd Ed. New York: John Wiley and Sons, 1968.

3. Brush, Brian C., "On the Large Scale Measurement of Plant Scale Economies." Industrial Organization Review, 1976, 134-41.

4. Caves, R. E., J. Khalilzadeh-Shirazi, and M. E. Porter, "Scale Economies in Statistical Analyses of Market Power." Review of Economics and Statistics, May 1975, 133-40.

5. Miller, Edward M., "The Extent of Economies of Scale: The Effects of Firm Size on Labor Productivity and Wage Rates." Southern Economic Journal, January 1978, 470-87.

6. Pratten, C. F. Economies of Scale in Manufacturing Industry. Cambridge: Cambridge University Press, 1971.

7. Saving, Thomas R., "Estimation of the Optimum Size of Plant by the Survivor Technique." Quarterly Journal of Economics, November 1961, 569-607.

8. Scherer, F. M. Industrial Market Structure and Economic Performance. Chicago: Rand McNally, 1970.

9. - Alan Beckenstein, Erich Kaufer, and R. Dennis Murphy. The Economics of Multiplant Operation: An International Comparisons Study. Cambridge, Mass.: Harvard University Press, 1975.

10. Shepherd, William G., "What Does the Survivor Technique Show About Economies of Scale?" Southern Economic Journal, July 1967, 113-22.

11. - The Economics of Industrial Organization. Englewood Cliffs, N.J.: Prentice-Hall, 1979.

12. Stigler, George J., "The Economies of Scale." Journal of Law and Economics, October 1958, 54-71.

13. U.S. Bureau of the Census, 1967 Census of Manufactures, Special Report MC67(S)-2.3. Concentration Ratios in Manufacturing, Part 3. Washington: U.S. Government Printing Office, 1971.

14. U.S. Bureau of the Census, 1972 Census of Manufactures, Special Report MC72(SR)-2. Concentration Ratios in Manufacturing, Washington: U.S. Government Printing Office, 1975.

15. Weiss, Leonard W., "The Survival Technique and the Extent of Suboptimal Capacity." Journal of Political Economy, June 1964, 246-61. 